\title{
Evolution of Mercury from Iron Ores in Temperature-Programmed Heat Treatments
}

\author{
Javzandolgor BUD, Yuuki MOCHIZUKI and Naoto TSUBOUCHI* \\ Center for Advanced Research of Energy and Materials, Faculty of Engineering, Hokkaido University, Kita 13 Nishi 8, Kita-ku, \\ Sapporo, 060-8628 Japan.
}

(Received on June 30, 2021; accepted on September 17, 2021)

\begin{abstract}
The behavior of $\mathrm{Hg}$ released from iron ores during temperature-programmed heat treatments (TPHTs) in air has been mainly studied using an online monitoring method. The Hg release behavior in TPHT significantly depends on the type of ore being processed, which includes forms evolved as $\mathrm{Hg}^{0}$ and $\mathrm{Hg}^{2+}$, and forms that remain thermally stable up to $950^{\circ} \mathrm{C}$. In addition, the TPHT experiments for model $\mathrm{Hg}$ compounds suggested the presence of several types of $\mathrm{Hg}$ forms $\left(\mathrm{HgCl}_{2}, \mathrm{Hg}_{2} \mathrm{Cl}_{2}, \mathrm{HgS}, \mathrm{HgO}, \mathrm{HgSO}\right.$, and associated mineral-Hg) in the iron ores used. The amounts and proportions of suggested forms of $\mathrm{Hg}$ species substantially depend on the type and composition of the iron ore used. These observations may be important in designing an efficient method for the removal of $\mathrm{Hg}$ from iron ore and gaseous $\mathrm{Hg}$.
\end{abstract}

KEY WORDS: iron ore; temperature-programmed heat treatment; mercury; evolution; ironmaking.

\section{Introduction}

Mercury is one of the most hazardous elements, and it spreads into the environment from many sources. The total amount of mercury emitted in nature was $2500 \pm 500 \mathrm{t} /$ year in $2018,{ }^{1)}$ and the mercury emitted in the environment does not disappear or fade away, instead, it changes its form, and exists in nature for decades. Mercury emissions are not only a local problem anymore; they spread across the world through the air, water, and even via the food chain, and adversely affect human health. ${ }^{2)}$ Following the accelerated development of population and consumption, the manufacturing industry continues to grow annually; however, mercury emissions have become more dangerous in several sectors. ${ }^{3)}$ Most of the $\mathrm{Hg}$ emissions originate from Asia; in particular, East and Southeast Asia produce $39 \%$ of the total global emissions, and industrial fields and fossil fuel usage are the primary sources of $\mathrm{Hg}$ emissions in this region. Ferrous and non-ferrous metal productions are primary anthropogenic sources worldwide. ${ }^{4)}$ In the field of energy production, coal combustion has the highest percentage of mercury emission sources. Consequently, the control and reduction of emissions are one of the primary challenges facing the industry in this century. A number of scientists are working on the determination and measurement of mercury contents in coal and reported sufficient data to elucidate the emission process of $\mathrm{Hg}$ from coal combustion and pyrolysis. ${ }^{5-11)}$ Unfortunately, the information and

\footnotetext{
* Corresponding author: E-mail: tsubon@eng.hokudai.ac.jp
}

results available on the existence and evolution behavior of $\mathrm{Hg}$ from iron ore, which is a major raw material for the metallurgic industry and pig-iron and steel productions, are insufficient. However, the availability of data and information on the release forms and behavior of $\mathrm{Hg}$ will facilitate the improvement of the emission control and reduction technology. Recently, various $\mathrm{Hg}$ removal processes have been adopted, such as coal washing, air pollution control devices (APCDs), and wet flue gas desulfurization (FGD). ${ }^{12}$ ) However, improving the removal methods and elucidating the release behavior of $\mathrm{Hg}$ from iron ore, as well as mercury adsorption from steel production and iron ore applications, remains crucial. To define the existence of $\mathrm{Hg}$ species in iron ores and determine their release behavior from iron ore, this study was conducted to examine the interaction between $\mathrm{Hg}$ species and other substrates.

\section{Experimental}

\subsection{Iron Ore Sample}

One Australian limonite (AUL) and four types of hematite (INH, AUH, BRH, and ISH) mined from different countries (India, Australia, Brazil, and South Africa) were used in this study. These particle sizes were $-250 \mu \mathrm{m}$. All samples were obtained from the Japan Iron and Steel Federation. Table 1 presents the compositions of all iron ores used. The total $\mathrm{Fe}$ and $\mathrm{Hg}$ contents of the samples ranged from $57-67$ mass $\%$-dry and 79 to 305 dry $\mu \mathrm{g} / \mathrm{g}$, respectively. The gangue components and combined-water $\left(\mathrm{H}_{2} \mathrm{O}\right)$ content $\mathrm{s}$ in the samples (all in mass\%-dry) were as follows: 
ISIJ International, Vol. 62 (2022), No. 1

Table 1. Gangue components of iron ore samples used in this study.

\begin{tabular}{|c|c|c|c|c|c|c|c|c|c|c|c|c|c|c|}
\hline \multirow{2}{*}{ Sample } & \multirow{2}{*}{ Country } & \multirow{2}{*}{ Code } & \multicolumn{11}{|c|}{ Composition, mass $\%$-dry } & \multirow{2}{*}{$\mathrm{Hg} \mu \mathrm{g} / \mathrm{g}$} \\
\hline & & & Total-Fe & $\mathrm{Si}$ & $\mathrm{Al}$ & $\mathrm{Fe}(\mathrm{II})$ & $\mathrm{Mn}$ & $\mathrm{P}$ & $\mathrm{Ti}$ & $\mathrm{Ca}$ & $\mathrm{Mg}$ & $\mathrm{S}$ & $\mathrm{H}_{2} \mathrm{O}$ & \\
\hline Limonite & Australia & AUL & 57.1 & 2.3 & 1.2 & - & 0.09 & 0.04 & 0.07 & 0.16 & 0.11 & 0.01 & 9.16 & 101 \\
\hline Hematite & India & INH & 61.8 & 2.0 & 1.1 & 1.0 & 0.70 & 0.06 & 0.05 & 0.01 & 0.03 & 0.01 & 4.1 & 82 \\
\hline Hematite & Australia & AUH & 62.8 & 1.6 & 0.96 & 0.15 & 0.13 & 0.08 & 0.04 & 0.02 & 0.03 & 0.02 & 4.4 & 227 \\
\hline Hematite & Brazilia & $\mathrm{BRH}$ & 66.2 & 0.55 & 0.57 & - & 0.60 & 0.05 & 0.04 & 0.01 & 0.02 & 0.01 & 1.72 & 305 \\
\hline Hematite & South Africa & ISH & 66.9 & 1.2 & 0.5 & 0.3 & 0.02 & 0.05 & 0.02 & 0.05 & 0.01 & 0.01 & 0.37 & 79 \\
\hline
\end{tabular}

Si, 0.55-2.3; Al, 0.5-1.2; Mn, 0.02-0.7; P, 0.04-0.08; Ti, $0.02-0.07$; Ca, 0.01-0.16; Mg, 0.01-0.11; S, 0.01-0.02; and $\mathrm{H}_{2} \mathrm{O}, 0.37-9.16$ mass $\%$.

\subsection{Temperature-Programmed Heat Treatment (TPHT)}

The TPHT experimental was carried out by flow-type quartz made fixed-bed reactors. The apparatus was shown in Fig. S1 in Supporting Information. First, 5.0-g iron ore sample was charged in a quartz cell and placed into the reactor, and then the reactor was heated up to $950^{\circ} \mathrm{C}$ by a $10^{\circ} \mathrm{C} / \mathrm{min}$ rate in air flow. The temperature of the K-type thermocouple reactor was maintained. The details of this apparatus have been described in. ${ }^{12)}$

\subsection{TPHT for $\mathbf{H g}$ Pure Compounds and Mixtures of $\mathrm{Hg}$ Compounds and $\mathrm{Fe}_{2} \mathrm{O}_{3}$}

The TPHT operations of several model Hg compounds were also conducted to investigate the nature of $\mathrm{Hg}$ release from iron ore. As experimental samples, we prepared physical mixtures of iron oxide $(99.9 \%)$ with various commercially available $\mathrm{Hg}$ species ( $\mathrm{HgCl}(99 \%), \mathrm{HgCl}_{2}(99.5 \%)$, $\mathrm{HgS}(99 \%), \mathrm{HgO}(98 \%)$, and $\left.\mathrm{HgSO}_{4}(99 \%)\right)$ in proportions selected to ensure a mercury concentration of $100 \mathrm{mg} / \mathrm{g}$ for each mixture. Particle size of all reagents used were -250 $\mu \mathrm{m}$. It should be noted that the mercury content should originally be $100 \mu \mathrm{g} / \mathrm{g}$ to match the mercury concentration in the ore; however, the amount was significantly small that it was difficult to measure it by weight during the preparation of $\mathrm{Fe}_{2} \mathrm{O}_{3} / \mathrm{Hg}$ compound mixtures. The general term " $\mathrm{Hg}$ compound $/ \mathrm{Fe}_{2} \mathrm{O}_{3}$ " is used to refer to these mixtures. Mixture samples were subjected to TPHT via the procedure described above for iron ore, and total $\mathrm{Hg}$ was solely analyzed. In this study, the reproducibility and analytical errors were within $\pm 10 \%$ and $\pm 5 \%$, respectively, for measurements of gaseous $\mathrm{Hg}$ and $\mathrm{Hg}$ in the solid phase.

\subsection{Hg Analysis}

$\mathrm{Hg}$ was measured in the as-received iron ore and solid sample after the TPHT was conducted via mixed acid dissolution ${ }^{12)}$ and reduction using cold vapor atomic absorption spectrometry (AAS) (Hiranuma Sangyo, HG-450). Gaseous total-Hg, which evolved in TPHT, was analyzed at 1-s intervals by non-dispersive double-beam direct UV AAS using a mercury analyzer (Nihon Instruments, EMP(WLE)-2/SGM8) equipment and $\mathrm{SnCl}_{2}$ solution, while $\mathrm{Hg}^{0}$ was measured using a $\mathrm{KCl}$ solution instead of a $\mathrm{SnCl}_{2}$ solution. The apparatus was shown in Fig. S1 in Supporting Information. The amount of $\mathrm{Hg}^{2+}$ was calculated as the difference between the amount of total $\mathrm{Hg}$ released to the released amount of $\mathrm{Hg}^{0}$. The release amount of total $\mathrm{Hg}, \mathrm{Hg}^{0}$, and $\mathrm{Hg}^{2+}$ was calculated based on the respective amounts of their content in iron ores. $\mathrm{Hg}$ in the ore represents the $\mathrm{Hg}$ concentration in the as-received iron ore.

\section{Results and Discussion}

\subsection{Release Behavior of Total-Hg during TPHT of Iron Ore}

Figure 1 illustrates the release behavior of total $\mathrm{Hg}$ from iron ore samples during TPHT up to $950^{\circ} \mathrm{C}$ in an air environment. $\mathrm{Hg}$ release started at approximately $100^{\circ} \mathrm{C}$ for all samples; however, release profiles were entirely different for each sample used. For BRH (Fig. 1(a)), the Hg release profile exhibited main and shoulder peaks at $600^{\circ} \mathrm{C}$ and $800^{\circ} \mathrm{C}$, respectively. The $\mathrm{Hg}$ evolution was determined up to $950^{\circ} \mathrm{C}$. $\mathrm{Hg}$ release from AUH (Fig. 1(b)) exhibited broad peaks at $150^{\circ} \mathrm{C}$ and $550^{\circ} \mathrm{C}$, and a distinct major peak was observed at $750-800^{\circ} \mathrm{C}$. Figure 1 (c) illustrates the $\mathrm{Hg}$ release profile of the INH. $\mathrm{Hg}$ release was observed at $200^{\circ} \mathrm{C}$, and broad main peaks were measured at approximately $600^{\circ} \mathrm{C}$. In the case of ISH (Fig. 1(d)), three broad peaks were observed at approximately $200^{\circ} \mathrm{C}, 500^{\circ} \mathrm{C}$, and $700^{\circ} \mathrm{C}$, respectively. For AUL (Fig. 1(e)), Hg was released above $100^{\circ} \mathrm{C}$, and the release profile exhibited shoulder and main peaks at approximately $300^{\circ} \mathrm{C}$ and $350^{\circ} \mathrm{C}$, respectively. Almost no $\mathrm{Hg}$ release was observed above $500^{\circ} \mathrm{C}$. From these results, it was determined that the total $\mathrm{Hg}$ release profile depends on the iron ore type. In other words, the evolution profiles indicate that $\mathrm{Hg}$ species in ores may exist in at least four forms (i.e., volatile forms below $400^{\circ} \mathrm{C}$, at $400-600$ or $700^{\circ} \mathrm{C}$, at $600-950^{\circ} \mathrm{C}$, and at thermally stable temperatures up to $950^{\circ} \mathrm{C}$ ).

Figure 2 presents the mass balance of the TPHT examination. It was obtained by integrating the formation rate profiles for gaseous total $\mathrm{Hg}$ shown in Fig. 1. Gaseous-Hg and solid-Hg in residues ranged from $16 \%$ to $73 \%$ and $30 \%$ to $75 \%$, respectively. The mass balances were within a logical range of $100 \pm 10 \%$. The order of solid-Hg was $\mathrm{INH} \doteqdot$ $\mathrm{BRH}<\mathrm{AUH}<\mathrm{ISH} \ll$ AUL. It is observed that $\mathrm{Hg}$ in AUL exists in a form that is difficult to release. In contrast, almost $60 \%-70 \%$ of total $\mathrm{Hg}$ was released from all ore samples with ease, except for AUL. This may indicate that $\mathrm{Hg}$ exists in ores and the release-form because gaseous- $\mathrm{Hg}$ are relatively different. In accordance with previous studies, ${ }^{5-11)}$ most of the $\mathrm{Hg}$ content in coal evolves in the gaseous form at low temperatures during pyrolysis or combustion. In contrast, $30 \%-75 \%$ of the total $\mathrm{Hg}$ content of iron ore remain 

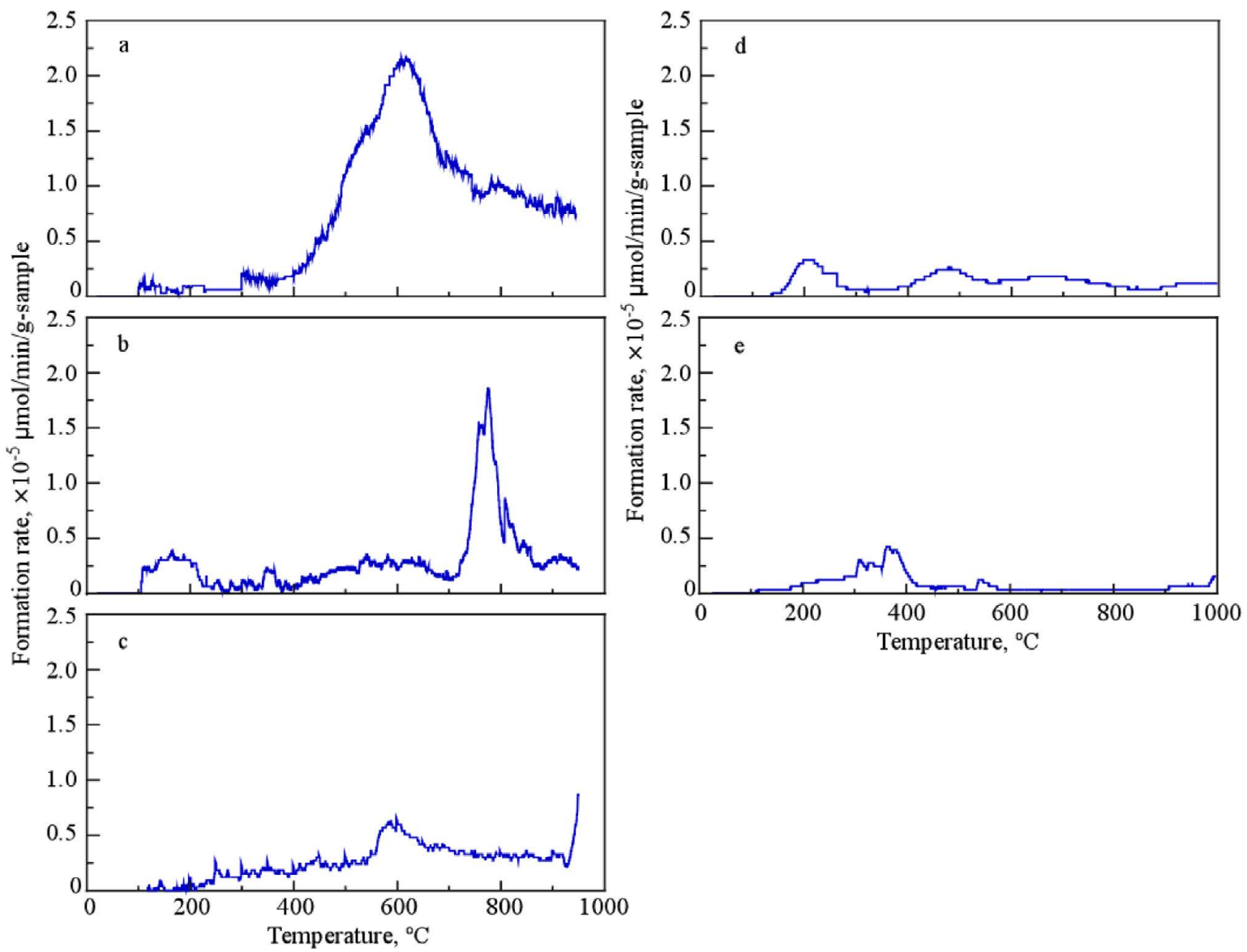

Fig. 1. Release behavior of total Hg during TPHT. (a) BRH, (b) AUH, (c) INH, (d) ISH, and (e) AUL. (Online version in color.)

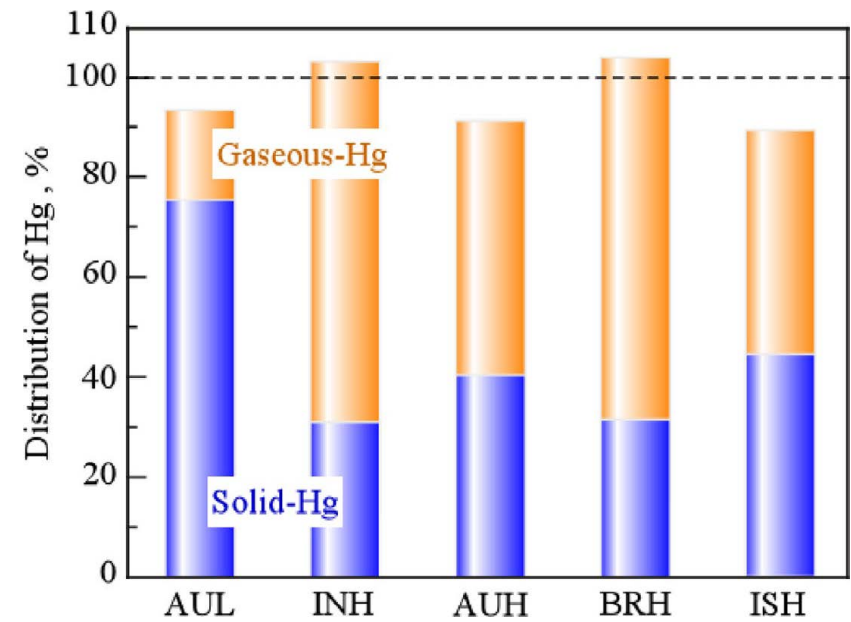

Fig. 2. Distribution of $\mathrm{Hg}$ contents for iron ore samples. (Online version in color.)

in the solid phase even after heating to $950^{\circ} \mathrm{C}$. These results suggest that the $\mathrm{Hg}$ content assume significantly different forms in iron ore and coal, which indicates that several thermally stable forms of $\mathrm{Hg}$ exist.

Figure 3 presents the results of the relationship between the $\mathrm{Hg}$ content in the ores presented in Table 1 and the amount of gaseous Hg in Fig. 2. Although there were a few variations for low $\mathrm{Hg}$-content ores, there was a positive correlation between the $\mathrm{Hg}$ content in the ores and the amount of gaseous $\mathrm{Hg}$.

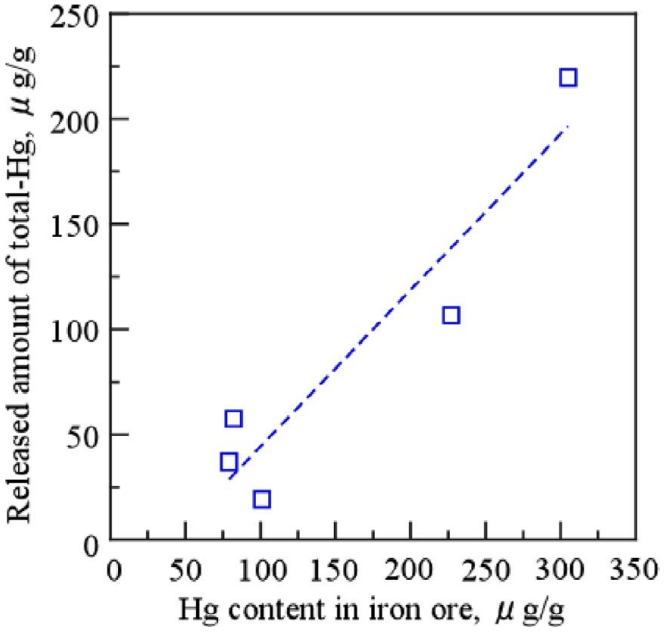

Fig. 3. Relationship between $\mathrm{Hg}$ content in as-received iron ore and released amount of total-Hg. (Online version in color.)

In other words, the ore with higher $\mathrm{Hg}$ content has more volatile $\mathrm{Hg}$ species, thus suggesting that the $\mathrm{Hg}$ content in the ore depends primarily on the thermally unstable mercury species. These results may also guide the development of methods to manage the $\mathrm{Hg}$ released during the thermal treatment of iron ore during the steelmaking process.

\subsection{Evolution Behavior of $\mathrm{Hg}^{0}$ and $\mathrm{Hg}^{2+}$ during TPHT}

The evolution profile of gaseous $\mathrm{Hg}^{0}$ during $\mathrm{TPTH}$ was investigated to elucidate the $\mathrm{Hg}$ forms in iron ore. The evo- 


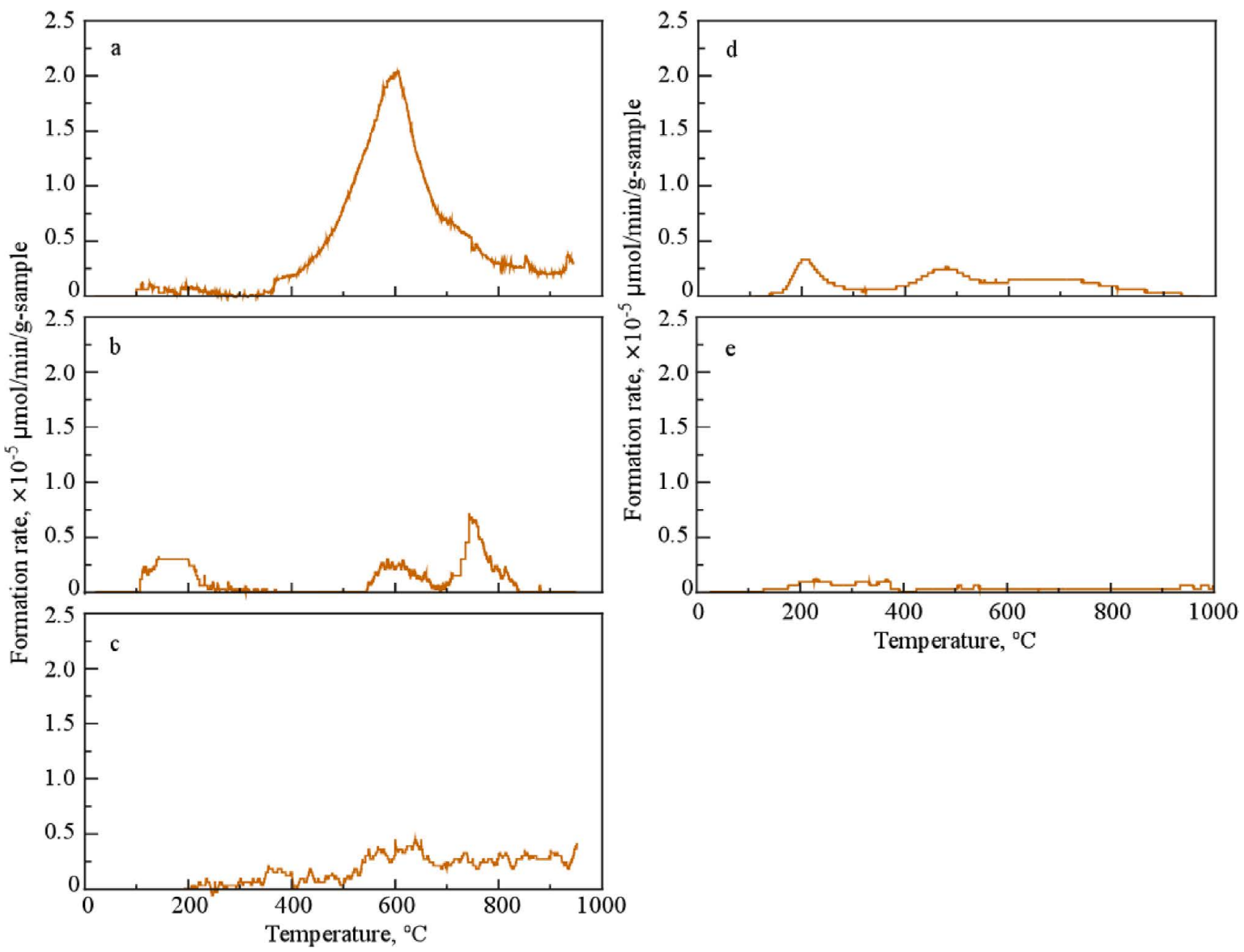

Fig. 4. Release profiles of $\mathrm{Hg}^{0}$ during TPHT. (a) BRH, (b) AUH, (c) INH, (d) ISH, and (e) AUL. (Online version in color.)
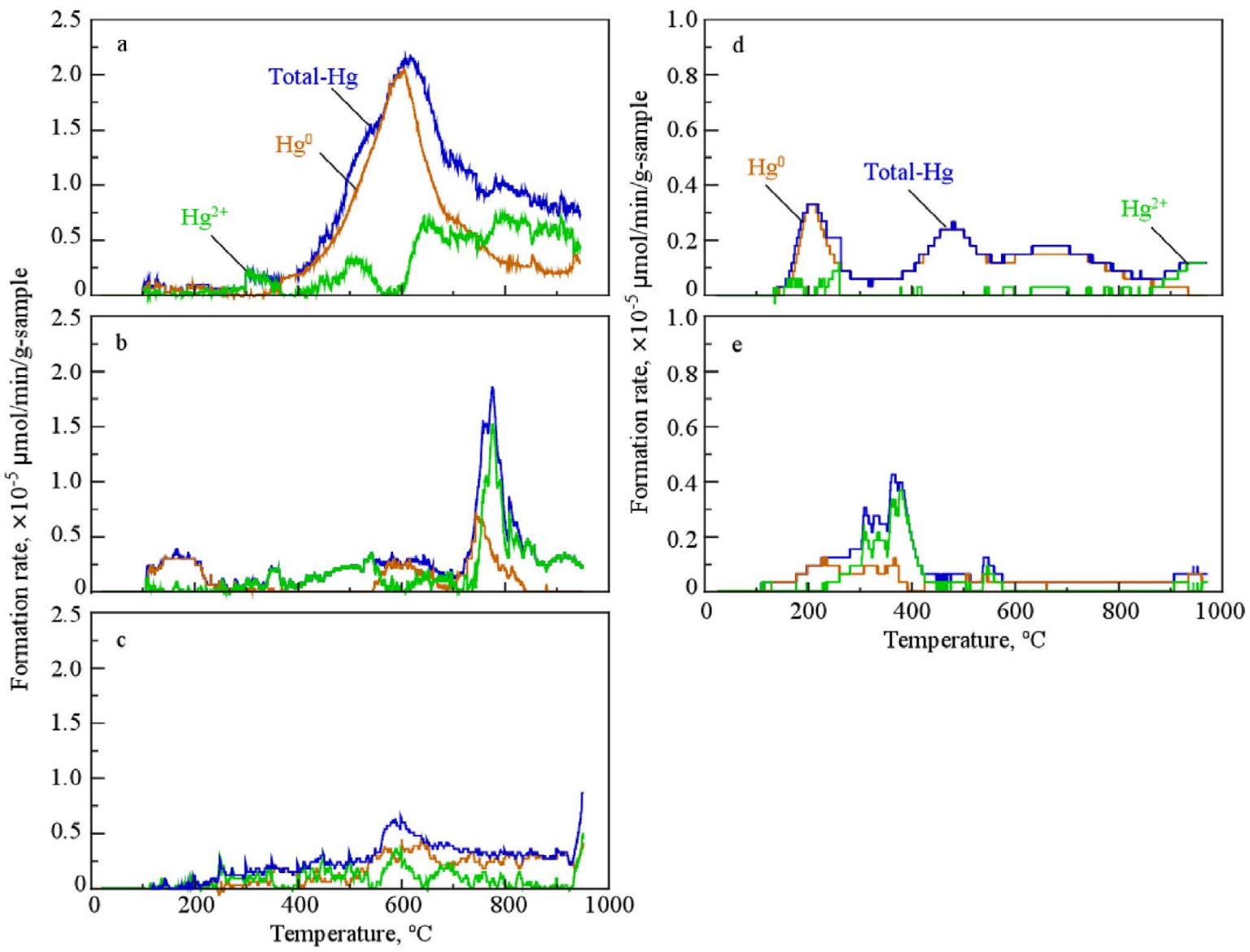

Fig. 5. Release profiles of $\mathrm{Hg}^{0}$ and $\mathrm{Hg}^{2+}$ forms during TPHT of iron ore. (a) BRH, (b) AUH, (c) INH, (d) ISH and (e) AUL. (Online version in color.) 
lution profiles of $\mathrm{Hg}^{0}$ from the ore samples are presented in Fig. 4. For the BRH sample (Fig. 4(a)), the $\mathrm{Hg}^{0}$ evolution profile exhibited a large and high-intensity peak at $610^{\circ} \mathrm{C}$. Figure 4(b) presents the $\mathrm{Hg}^{0}$ profiles of the AUH samples. Release started at $100^{\circ} \mathrm{C}$, and provided three smaller peaks than $\mathrm{BRH}$ at $150^{\circ} \mathrm{C}, 600^{\circ} \mathrm{C}$, and $750^{\circ} \mathrm{C} . \mathrm{Hg}^{0}$ evolution from INH (Fig. 4(c)) was observed at $200^{\circ} \mathrm{C}$, and the profile exhibited two small peaks at $550^{\circ} \mathrm{C}$ and $650^{\circ} \mathrm{C}$, and the $\mathrm{Hg}^{0}$ release continued until $950^{\circ} \mathrm{C}$. In the case of ISH (Fig. 4(d)), the $\mathrm{Hg}^{0}$ evolution profile exhibited two broad peaks at $200^{\circ} \mathrm{C}$ and $450^{\circ} \mathrm{C}$, and a shoulder peak at $700^{\circ} \mathrm{C}$. The evolution reached to $950^{\circ} \mathrm{C}$. In the case of AUL (Fig. 4(e)), almost no $\mathrm{Hg}^{0}$ evolution was observed. From these results, the $\mathrm{Hg}^{0}$ evolution also depends on the iron ore type.

Figure 5 summarizes the evolution profiles of the total $\mathrm{Hg}, \mathrm{Hg}^{0}$, and $\mathrm{Hg}^{2+}$. Here, the $\mathrm{Hg}^{2+}$ profiles were determined by calculating the difference between the total $\mathrm{Hg}$ and $\mathrm{Hg}^{0}$ evolution profiles. For BRH (Fig. 5(a)), the shoulder peak that was released at $500-550^{\circ} \mathrm{C}$ in the total $\mathrm{Hg}$ profile disappeared in the $\mathrm{Hg}^{0}$ profile, and the intensity of the main peak at $600^{\circ} \mathrm{C}$ was similar to the total $\mathrm{Hg}$ peak. Nevertheless, the intensity of detachment that appeared at $600-950^{\circ} \mathrm{C}$ was decreased. Compared with the total $\mathrm{Hg}$, the elimination amount of $\mathrm{Hg}^{0}$ decreased, which can be attributed to the increased $\mathrm{Hg}^{2+}$ elimination. In other words, in the high-temperature range, the total $\mathrm{Hg}$ content for the BRH release was in both $\mathrm{Hg}^{0}$ and $\mathrm{Hg}^{2+}$ forms. In Fig. 5(b), the release profile of total-Hg from AUH matched with $\mathrm{Hg}^{0}$ at $100-250^{\circ} \mathrm{C}$ and $550-700^{\circ} \mathrm{C}$ temperature ranges, while the $\mathrm{Hg}^{2+}$ profile matched total- $\mathrm{Hg}$ at $250-550^{\circ} \mathrm{C}$. Compared with the other sample profiles, AUH had the highest $\mathrm{Hg}^{2+}$ peak (at approximately $750^{\circ} \mathrm{C}$ ). In the case of INH (Fig. 5(c)), the total $\mathrm{Hg}$ profile was observed to be similar to that of $\mathrm{Hg}^{0}$ and $\mathrm{Hg}^{2+}$. Regarding the ISH (Fig. 5(d)), total- $\mathrm{Hg}$ and $\mathrm{Hg}^{0}$ nearly matched with each other, and $\mathrm{Hg}^{2+}$ release started above $850^{\circ} \mathrm{C}$. This shows that there is almost no release of $\mathrm{Hg}^{2+}$ from ISH up to $850^{\circ} \mathrm{C}$. For AUL (Fig. 5(e)), the main peak of the total-Hg appeared at a temperature range of $300-400^{\circ} \mathrm{C}$, and at that temperature range, $\mathrm{Hg}^{2+}$ also exhibited the main peak. These two peaks had approximately the same formation rate and exhibited a total $\mathrm{Hg}$ profile primarily originating from $\mathrm{Hg}^{2+}$. From these results, we can observe that the evolution behavior of $\mathrm{Hg}^{2+}$ similarly depends on the iron ore type.

Figure 6 presents the distribution of $\mathrm{Hg}$ forms during
TPHT for all five samples used in this study. The AUL sample has the highest percentage of solid-Hg and the lowest $\mathrm{Hg}^{2+}$, while AUH exhibits the highest $\mathrm{Hg}^{2+}$ content. The distribution percentages of $\mathrm{Hg}^{2+}$ increased in the following order: AUL $<$ ISH $<$ INH $<$ BRH $<$ AUH. When comparing INH, AUH, BRH, and ISH, the ores with higher Hg volatilization rates tend to emit mercury as $\mathrm{Hg}^{0}$.

Figure 7(a) presents the relationship between the amount of volatilized total $\mathrm{Hg}$ and $\mathrm{Hg}$ concentration in iron ore. There was a relatively optimal correlation between the amount of volatilized total $\mathrm{Hg}$ and $\mathrm{Hg}$ concentration. This correlation was also observed in the case of volatility based on percentage; however, the correlation coefficients were smaller than those in the case of volatility based on weight. A positive correlation was also observed between the $\mathrm{Hg}^{0}$ and $\mathrm{Hg}^{2+}$ volatiles (Fig. 7(b)). In addition, released amounts of total $\mathrm{Hg}$ and $\mathrm{Hg}^{2+}$ or $\mathrm{Hg}^{0}$ exhibit a good positive correlation (Fig. 7(c)). These results indicate that the higher the amount of $\mathrm{Hg}$ in the ore, the more $\mathrm{Hg}$ content to be volatilized as $\mathrm{Hg}^{0}$.

Next, to examine the effect of ore content on $\mathrm{Hg}$ volatilization, we examined the relationship between $\mathrm{Hg}$ volatilization and each element content, as presented in Table 1, and the results obtained are shown in Fig. 8. Although variations exist (Fig. 8(a)), a linear negative correlation is observed among the total $\mathrm{Hg}, \mathrm{Hg}^{0}, \mathrm{Hg}^{2+}$, and $\mathrm{Si}$ content in the ores. However, a curved negative correlation exists

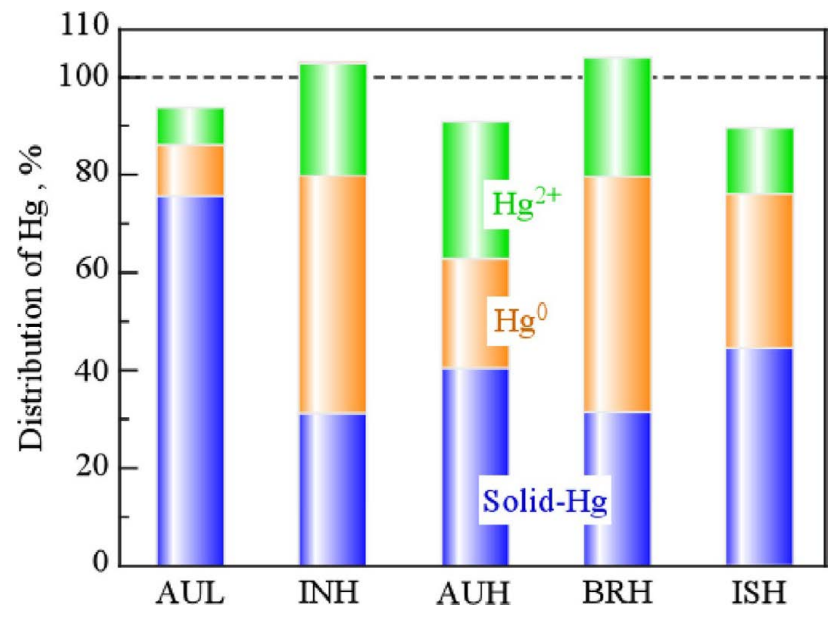

Fig. 6. Distribution of $\mathrm{Hg}$ forms during TPHT. (Online version in color.)
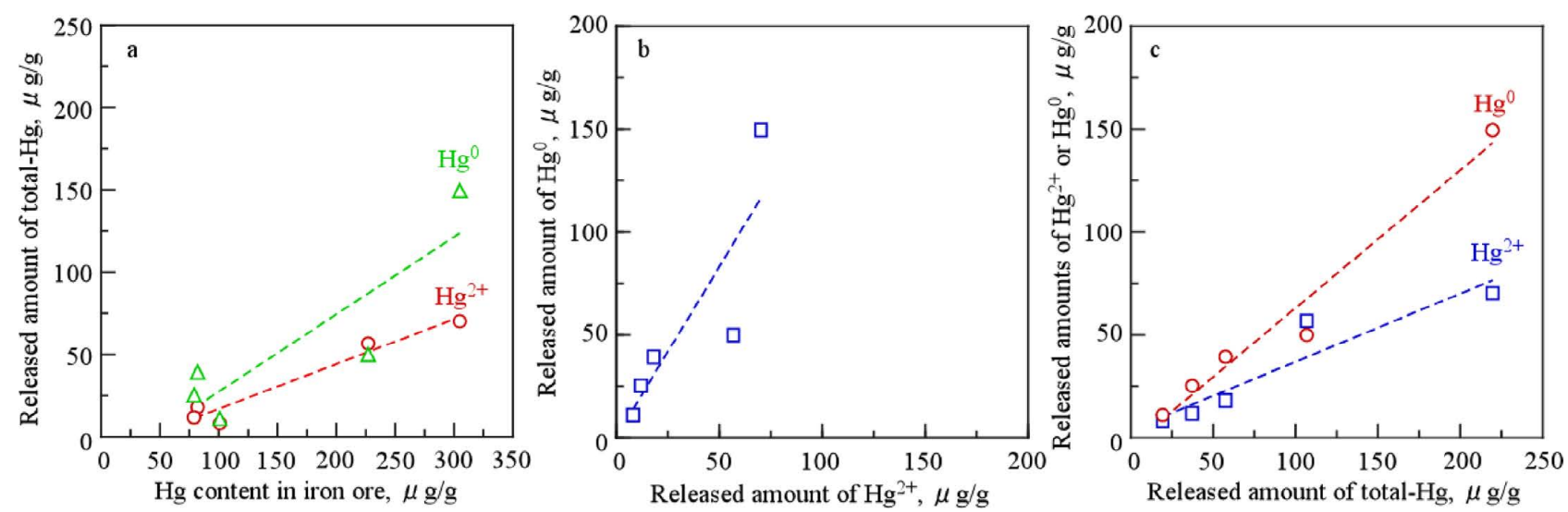

Fig. 7. Relationship among $\mathrm{Hg}$ content in iron ore, released amount of total- $\mathrm{Hg}_{\mathrm{Hg}} \mathrm{Hg}^{2+}$, or $\mathrm{Hg}^{0}$. (Online version in color.) 

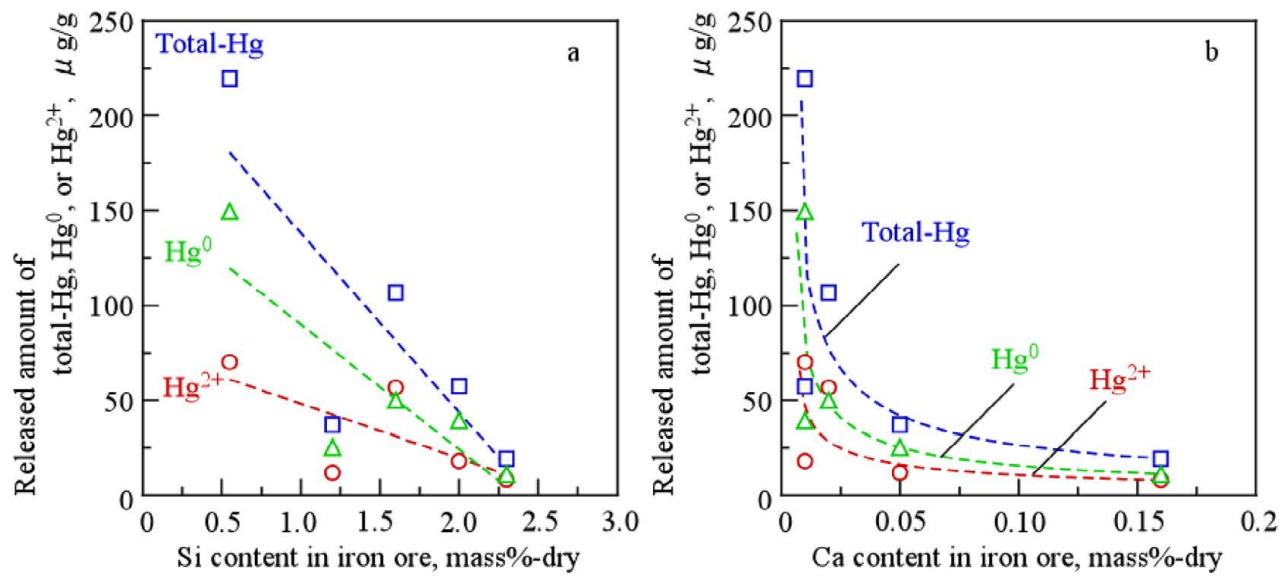

Fig. 8. Relationship between gangue components and released amount of total- $\mathrm{Hg}, \mathrm{Hg}^{2+}$ or $\mathrm{Hg}^{0}$. (a) Si content, (b) Ca content. (Online version in color.)
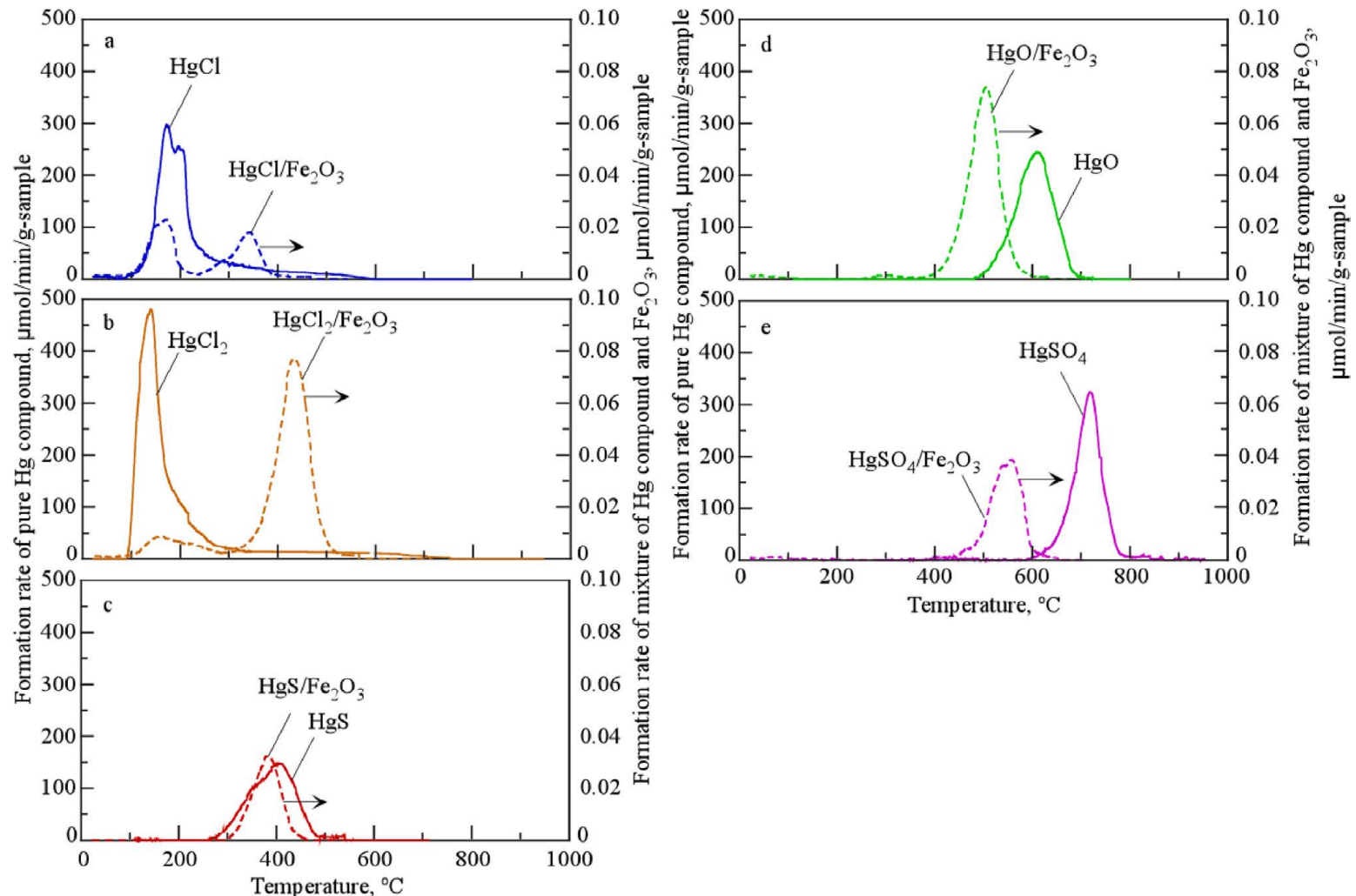

Fig. 9. Release profiles of total- $\mathrm{Hg}$ from pure $\mathrm{Hg}$-compounds and mixture of $\mathrm{Hg}$ compound and $\mathrm{Fe}_{2} \mathrm{O}_{3}$ (a) $\mathrm{HgCl}$ and $\mathrm{HgCl} / \mathrm{Fe}_{2} \mathrm{O}_{3}$, (b) $\mathrm{HgCl}_{2}$ and $\mathrm{HgCl}_{2} / \mathrm{Fe}_{2} \mathrm{O}_{3}$, (c) $\mathrm{HgS}$ and $\mathrm{HgS} / \mathrm{Fe}_{2} \mathrm{O}_{3}$, (d) $\mathrm{HgO}$ and $\mathrm{HgO} / \mathrm{Fe}_{2} \mathrm{O}_{3}$, and (e) $\mathrm{HgSO}_{4}$ and $\mathrm{HgSO}_{4} / \mathrm{Fe}_{2} \mathrm{O}_{3}$. (Online version in color.)

between the $\mathrm{Ca}$ content and total $\mathrm{Hg}, \mathrm{Hg}^{0}$, and $\mathrm{Hg}^{2+}$; and the amount of gaseous $\mathrm{Hg}$ tends to decrease with increasing $\mathrm{Ca}$ content in the ores. Although the $\mathrm{Si}$ and $\mathrm{Ca}$ contents in the ore are overwhelmingly larger than those of $\mathrm{Hg}$, the increase in the content of these species may influence $\mathrm{Hg}$ release. A detailed investigation on this issue is a topic for future research.

\subsection{Hg Release during TPHT of Model Compounds}

To investigate the volatilization form of $\mathrm{Hg}$ from iron ore, the total $\mathrm{Hg}$ evolution behavior of pure $\mathrm{Hg}$ compounds during TPHT is shown in Fig. 9, and the results are summarized in Table 2. The evolution of $\mathrm{Hg}$ from $\mathrm{HgCl}$ also starts above $100^{\circ} \mathrm{C}$, and the evolution profile peaks at approximately $180^{\circ} \mathrm{C}$ and $200^{\circ} \mathrm{C}$. The evolution behavior of $\mathrm{Hg}$ from these two pure Hg compounds exhibits asymmetric evolution profiles. However, $\mathrm{HgS}, \mathrm{HgO}$, and $\mathrm{HgSO}_{4}$ exhibit symmetrical profiles with peaks of $\mathrm{Hg}$ evolution rate at approximately $400^{\circ} \mathrm{C}, 600^{\circ} \mathrm{C}$, and $700^{\circ} \mathrm{C}$, respectively. The order of the evolution peak temperatures was $\mathrm{HgCl}_{2}<\mathrm{HgCl}<\mathrm{HgS}<$ $\mathrm{HgO}<\mathrm{HgSO}_{4}$. This order was consistent with previous reports on the TPHT of pure $\mathrm{Hg}$ compound species. ${ }^{7,8,13)}$ In contrast, the maximum TPHT peak temperatures of $\mathrm{HgO}$, $\mathrm{HgS}$, and $\mathrm{HgSO}_{4}$ in this study (Table 2) appear at higher temperatures than those of other research groups using air atmosphere ${ }^{14-17)}$ however, the above three species were in close agreement with previous reports that adopted nitrogen atmosphere. ${ }^{18)}$ Although Hg-TPHT has been conducted by several researchers to investigate the morphology of $\mathrm{Hg}$ in samples such as coal, coal ash, and gypsum, the maximum 
Table 2. Summaries for Hg-TPHT results of pure $\mathrm{Hg}$ compounds and physical mixture of $\mathrm{Fe}_{2} \mathrm{O}_{3}$ and pure $\mathrm{Hg}$ compounds.

\begin{tabular}{|c|c|c|c|c|c|c|}
\hline \multirow{3}{*}{ Hg species } & \multicolumn{4}{|c|}{ Pure Hg compounds } & \multirow{2}{*}{\multicolumn{2}{|c|}{$\mathrm{Fe}_{2} \mathrm{O}_{3}$ mixture }} \\
\hline & \multicolumn{2}{|c|}{ Present work } & \multicolumn{2}{|c|}{ Ref. [19] } & & \\
\hline & Peak temp., ${ }^{\circ} \mathrm{C}$ & Range, ${ }^{\circ} \mathrm{C}$ & Peak temp., ${ }^{\circ} \mathrm{C}$ & Range, ${ }^{\circ} \mathrm{C}$ & Peak temp., ${ }^{\circ} \mathrm{C}^{\mathrm{b}}$ & Range, ${ }^{\circ} \mathrm{C}$ \\
\hline $\mathrm{HgCl}_{2}$ & 150 & $100-700$ & $138 \pm 4$ & $90-350$ & $180(\mathrm{~m}), 400(\mathrm{~s})$ & $100-550$ \\
\hline $\mathrm{Hg}_{2} \mathrm{Cl}_{2}$ & 180,200 & $100-600$ & $119 \pm 9$ & $60-250$ & $180(\mathrm{w}), 350(\mathrm{~s})$ & $90-450$ \\
\hline $\mathrm{HgO}$ (red) & 600 & $500-700$ & $308 \pm 1,471 \pm 5$ & $200-360,370-530$ & $500(\mathrm{~s})$ & $400-600$ \\
\hline $\mathrm{HgS}$ & 400 & $250-500$ & n.a. ${ }^{\text {a }}$ & n.a. ${ }^{a}$ & $450(\mathrm{~m})$ & $300-450$ \\
\hline $\mathrm{HgSO}_{4}$ & 720 & $600-800$ & $583 \pm 8$ & $500-600$ & $550(\mathrm{~m})$ & $420-650$ \\
\hline
\end{tabular}

${ }^{a}$ Not analysis. ${ }^{b}$ Peak intensity Designated by Hg-TPHT: w (weak), m (medium), s (strong).

TPHT peak temperature and evolution temperature of pure $\mathrm{Hg}$ compound species are different..$^{7-9,14,15,18-24)}$ Previous studies investigating $\mathrm{Hg}$ morphology in solids derived from coal utilization and gypsum via TPHT partitioned the peaks above $600^{\circ} \mathrm{C}$ into $\mathrm{HgSO}_{4}$ peaks. ${ }^{9,19)}$ Considering the above points, the results of the TPHT in Table 2 are considered logical. It is well known that the decomposition of $\mathrm{HgCl}_{2}, \mathrm{HgCl}, \mathrm{HgS}, \mathrm{HgO}$, and $\mathrm{HgSO}_{4}$ in air follows Eqs. (1)-(9). ${ }^{24,25)}$

$$
\begin{aligned}
& \mathrm{Hg}_{2} \mathrm{Cl}_{2} \rightarrow \mathrm{Hg}^{0}(\mathrm{~g})+\mathrm{HgCl}_{2}(\mathrm{~g}) \\
& \mathrm{HgCl}_{2} \rightarrow \mathrm{Hg}^{0}(\mathrm{~g})+\mathrm{Cl}_{2}(\mathrm{~g}) \\
& \mathrm{HgO} \rightarrow \mathrm{Hg}^{0}(\mathrm{~g})+0.5 \mathrm{O}_{2}(\mathrm{~g}) \\
& \mathrm{HgO} \rightarrow \mathrm{Hg}^{0}(\mathrm{~g})+\mathrm{O} \cdot(\mathrm{g}) \\
& \mathrm{Hg}^{0}(\mathrm{~g})+\mathrm{O} \cdot(\mathrm{g}) \rightarrow \mathrm{Hg}_{2} \mathrm{O}(\mathrm{g}) \\
& \mathrm{HgS} \rightarrow \mathrm{Hg}^{0}(\mathrm{~g})+0.5 \mathrm{~S}_{2}(\mathrm{~s}) \\
& \mathrm{HgS}+\mathrm{O}_{2}(\mathrm{~g}) \rightarrow \mathrm{Hg}^{0}(\mathrm{~g})+\mathrm{SO}_{2}(\mathrm{~g}) \\
& \mathrm{HgSO}_{4} \rightarrow 1 / 3 \mathrm{HgSO}_{4} \cdot 2 \mathrm{HgO}(\mathrm{s})+2 \mathrm{SO}_{2}(\mathrm{~g})+\mathrm{O}_{2}(\mathrm{~g}) \ldots \\
& \mathrm{HgSO}_{4} \cdot 2 \mathrm{HgO}(\mathrm{s}) \rightarrow 3 \mathrm{Hg}^{0}(\mathrm{~g})+\mathrm{SO}_{2}(\mathrm{~g})+2 \mathrm{O}_{2}(\mathrm{~g}) . .
\end{aligned}
$$

However, the $\mathrm{Hg}$ elimination reaction from $\mathrm{HgS}$ and $\mathrm{HgSO}_{4}$ is unclear, ${ }^{25)}$ and it has been reported that the $\mathrm{HgSO}_{4} \cdot 2 \mathrm{HgO}$ produced in Eq. (8) was thermally stable up to $600^{\circ} \mathrm{C}^{24)}$ The complexity of the reaction may also be responsible for the different $\mathrm{Hg}$-TPHT results in different research groups. Although there are some problems with the TPHT described above, the results of $\mathrm{Hg}$ evolution from iron ore can be compared with the results presented in Table 2 , because the evolution behavior of $\mathrm{Hg}$ from ore and the TPHT of pure $\mathrm{Hg}$ compounds were carried out in the same apparatus and reaction conditions (temperature rise rate and atmosphere) in this study.

Figure 9 also presents the results of $\mathrm{Hg}$ evolution from a mixture of $\mathrm{Fe}_{2} \mathrm{O}_{3} / \mathrm{Hg}$ compounds. The evolution of $\mathrm{Hg}$ from $\mathrm{HgCl} / \mathrm{Fe}_{2} \mathrm{O}_{3}$ is observed above $100^{\circ} \mathrm{C}$, and the profile exhibits two peaks at $180^{\circ} \mathrm{C}$ and $350^{\circ} \mathrm{C}$, respectively (Fig. 9(a)). Interestingly, this profile is relatively different from that of $\mathrm{HgCl}$, and a new peak appears at $350^{\circ} \mathrm{C}$. The evolution of $\mathrm{Hg}$ from $\mathrm{HgCl}_{2} / \mathrm{Fe}_{2} \mathrm{O}_{3}$ is observed above $100^{\circ} \mathrm{C}$. It exhibits an asymmetric weak peak at approximately $180^{\circ} \mathrm{C}$, and then decreased at $300^{\circ} \mathrm{C}$. Although the evolution profile of $\mathrm{Hg}$ from $\mathrm{HgCl}_{2}$ is not observed above $300^{\circ} \mathrm{C}$ (Fig. 9(b)), a large peak appears at approximately $420^{\circ} \mathrm{C}$ for the $\mathrm{HgCl}_{2} /$ $\mathrm{Fe}_{2} \mathrm{O}_{3}$ mixture. This tendency is similar to that of the $\mathrm{HgCl}$ / $\mathrm{Fe}_{2} \mathrm{O}_{3}$ mixture.

$\mathrm{HgS} / \mathrm{Fe}_{2} \mathrm{O}_{3}$ exhibits a similar $\mathrm{Hg}$ evolution behavior to that of the pure compound. In contrast, the $\mathrm{Hg}$ evolution rates of $\mathrm{HgO} / \mathrm{Fe}_{2} \mathrm{O}_{3}$ (Fig. 9(d)) and $\mathrm{HgSO}_{4} / \mathrm{Fe}_{2} \mathrm{O}_{3}$ (Fig. 9(e)) exhibit symmetrical evolution profiles with velocity peaks at approximately $500^{\circ} \mathrm{C}$ and $550^{\circ} \mathrm{C}$, respectively. The evolution behavior of $\mathrm{Hg}$ from the physical mixture of $\mathrm{Hg}$ compounds and $\mathrm{Fe}_{2} \mathrm{O}_{3}$, excluding $\mathrm{HgS}$, relatively differs from that of pure $\mathrm{Hg}$. In other words, two peaks are observed for $\mathrm{Hg}$ chloride $/ \mathrm{Fe}_{2} \mathrm{O}_{3}$, and the peak temperatures of $\mathrm{HgO}$ and $\mathrm{HgSO}_{4} / \mathrm{Fe}_{2} \mathrm{O}_{3}$ shift to lower temperatures compared to those of the pure compound. The 1st peak observed at approximately $200^{\circ} \mathrm{C}$ for $\mathrm{HgCl}$ or $\mathrm{HgCl}_{2} / \mathrm{Fe}_{2} \mathrm{O}_{3}$ was derived from $\mathrm{HgCl}$ and $\mathrm{HgCl}_{2}$, respectively. However, because the 2nd peak is not observed in the pure compound, it is considered to be triggered by the evolution of $\mathrm{HgCl}$ and $\mathrm{HgCl}_{2}$ species interacting with $\mathrm{Fe}_{2} \mathrm{O}_{3}$ during the heating process. According to previous reports, the adsorption of gaseous $\mathrm{Hg}^{0}$ on $\mathrm{Fe}_{2} \mathrm{O}_{3}$ does not occur. ${ }^{26)}$ Therefore, the above interaction may be triggered by the solid-solid reaction between the $\mathrm{HgCl}$ species and $\mathrm{Fe}_{2} \mathrm{O}_{3}$. However, the peak temperatures of $\mathrm{HgO} / \mathrm{Fe}_{2} \mathrm{O}_{3}$ and $\mathrm{HgSO}_{4} / \mathrm{Fe}_{2} \mathrm{O}_{3}$ shift to lower temperatures. A similar shift of the TPHT peak was reported in a previous study of the Hg-TPHT of a mixture of various $\mathrm{Hg}$ compounds and some substrates $\left(\mathrm{SiO}_{2}, \mathrm{CaSO}_{4} \cdot 2 \mathrm{H}_{2} \mathrm{O}\right) .{ }^{24)}$ It has been speculated that the decrease in the peak temperature of the $\mathrm{Hg}$ evolution profile was owing to the autocatalysis reaction by the substate. ${ }^{24,27)}$ Therefore, the decrease in the $\mathrm{Hg}$ evolution peak temperature from the $\mathrm{HgO}$ and $\mathrm{HgSO}_{4} /$ $\mathrm{Fe}_{2} \mathrm{O}_{3}$ mixed samples may be triggered by $\mathrm{Fe}_{2} \mathrm{O}_{3}$ acting as a catalyst. The details of this discussion will be the topic for future research.

According to previous studies that investigated the behavior of $\mathrm{Hg}$ release from coal, bauxite, and sequential leached coal, the $\mathrm{Hg}$ species released at high temperatures above $600^{\circ} \mathrm{C}$ are those associated with silicate, ${ }^{5,6,15)}$ montmorillonite, ${ }^{10)}$ refractory silicate, and mineral matrices. ${ }^{11)}$ Consequently, the high-temperature $\mathrm{Hg}$ release observed at $\geq 600^{\circ} \mathrm{C}$ for all ores may be owing to the mineral matter present in ores. 


\subsection{Proportion of $\mathbf{H g}$ Species Evolved during TPHT}

Based on the results presented in Fig. 9, Fig. 10 shows the results of the curve fitting of the $\mathrm{Hg}$ evolution profile observed in Fig. 3. Here, $\mathrm{HgCl}_{\mathrm{Fe} 2 \mathrm{O} 3}$ and $\mathrm{HgCl}_{\mathrm{Fe} 2 \mathrm{O} 3}$ in Fig. 10 depict the $\mathrm{Hg}$ species that interacted with $\mathrm{Fe}_{2} \mathrm{O}_{3}$, as shown in Fig. 9. Table 3 presents the proportion of $\mathrm{Hg}$ forms calculated based on the curve-fitting results. As shown in Fig. 10 , the $\mathrm{Hg}$ species volatilized above $600^{\circ} \mathrm{C}$ was not identified in this study; hence, the $\mathrm{Hg}$ species are unknown. In the AUL, $\mathrm{Hg}$ species that evolved until $600^{\circ} \mathrm{C}$ were mainly classified as $\mathrm{HgCl}, \mathrm{HgCl}_{\mathrm{Fe} 2 \mathrm{O} 3}, \mathrm{HgS}$, and $\mathrm{HgO}$. According to curve-fitting, $\mathrm{HgS}$ is the most abundant species, followed by unknown species, and $\mathrm{HgCl}_{\mathrm{Fe} 2 \mathrm{O} 3}$ species accounts for a significant proportion. In the INL, the $\mathrm{Hg}$ forms volatilized below $600^{\circ} \mathrm{C}$ are assigned to $\mathrm{HgCl}_{\mathrm{Fe} 2 \mathrm{O} 3}, \mathrm{HgS}, \mathrm{HgCl}_{2 \mathrm{Fe} 2 \mathrm{O} 3}$, $\mathrm{HgO}$, and $\mathrm{HgSO}_{4}$, and the presence of $\mathrm{HgCl}_{2}$ and $\mathrm{HgCl}$ species is not observed. The $\mathrm{Hg}$ species volatilized above $600^{\circ} \mathrm{C}$ were unknown species. In INL, although the presence of $\mathrm{HgCl}_{2}$ was not observed, $\mathrm{HgCl}_{2} \mathrm{Fe}_{2 \mathrm{O}}$ was detected. Using the model compounds described above, $\mathrm{HgCl}_{2 \mathrm{Fe} 2 \mathrm{O} 3}$ may be assigned as the source owing to the secondary reaction with $\mathrm{HgCl}_{2}$ and $\mathrm{Fe}_{2} \mathrm{O}_{3}$ from the experimental results (Fig. 9). In AUH, $\mathrm{HgCl}_{2}, \mathrm{HgCl}, \mathrm{HgO}$, and $\mathrm{HgSO}_{4}$ account for most of the volatile species below $600^{\circ} \mathrm{C}$, and $\mathrm{HgCl}_{\mathrm{Fe} 2 \mathrm{O} 3}, \mathrm{HgS}$, and $\mathrm{HgCl}_{2 \mathrm{Fe} 2 \mathrm{O} 3}$ are observed in small amounts. Similar to the
INL, unknown species account for most of the volatile species. The volatile $\mathrm{Hg}$ species in the ISH mainly comprise $\mathrm{HgCl}, \mathrm{HgCl}_{2 \mathrm{Fe} 2 \mathrm{O} 3}, \mathrm{HgO}$, and $\mathrm{HgSO}_{4}$, with small amounts of $\mathrm{HgCl}_{\mathrm{Fe} 2 \mathrm{O} 3}$ and $\mathrm{HgS}$. In addition, half of the volatiles are unknown. Although unknown species account for $80 \%$ of the volatiles from $\mathrm{BRH}$, the others comprise $\mathrm{HgO}$ and $\mathrm{HgSO}_{4}$. From these results, it was determined that the forms of $\mathrm{Hg}$ evolution below $600^{\circ} \mathrm{C}$ were primarily assigned to $\mathrm{HgCl}_{2}$ and $\mathrm{HgCl} . \mathrm{HgCl}_{\mathrm{Fe} 2 \mathrm{O} 3}, \mathrm{HgS}, \mathrm{HgCl}_{2 \mathrm{Fe} 2 \mathrm{O} 3}, \mathrm{HgO}$, and $\mathrm{HgSO}_{4}$, and their proportions depended on the type of iron ore.

The present study simulates the desorption behavior of mercury in the sintering process of iron ore. However, in the sintering process, carbonaceous substances for combustion and materials for adjusting basicity are added to iron ore. These substances are thought to affect the mercury desorption from iron ore during heating treatment. In the future, it will be important to study the mixture of iron ore with carbonaceous and basicity adjustment substances.

\section{Conclusions}

This study is focused on the determination of $\mathrm{Hg}$ release forms and profiles from iron ore during temperature-programmed heat treatment. The evolution behavior of $\mathrm{Hg}$ in
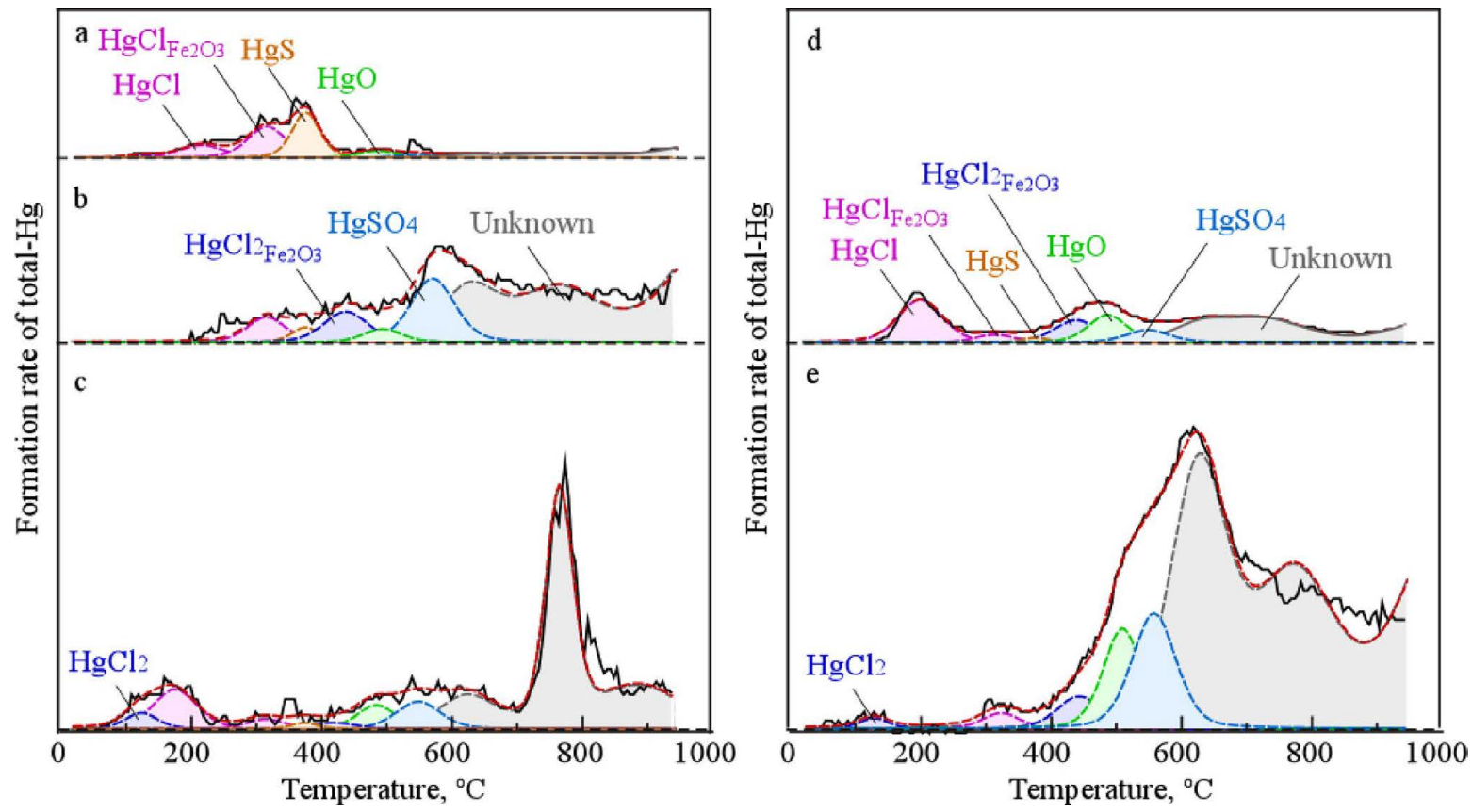

Fig. 10. Proportion of the Hg-species that evolved during TPTH. (a) AUL, (b) INH, (c) AUH, (d) ISH, and (e) BRH. (Online version in color.)

Table 3. Summary of information in Fig. 9 and proportion of $\mathrm{Hg}$ forms.

\begin{tabular}{ccrrrrrrr}
\hline \multirow{2}{*}{ Sample } & \multicolumn{7}{c}{ Proportion of $\mathrm{Hg}$ evolution form, \%-evolution basis } \\
\cline { 2 - 9 } & $\mathrm{HgCl}_{2}$ & $\mathrm{HgCl}$ & $\mathrm{HgCl}_{\mathrm{Fe} 203}$ & $\mathrm{HgS}$ & $\mathrm{HgCl}_{2 \mathrm{Fe} 203}$ & $\mathrm{HgO}$ & $\mathrm{HgSO}_{4}$ & Unknown \\
\hline $\mathrm{AUL}$ & 2 & 9 & 16 & 36 & 0 & 5 & 3 & 29 \\
$\mathrm{INH}$ & 0 & 0 & 3 & 3 & 5 & 3 & 16 & 70 \\
$\mathrm{AUH}$ & 3 & 5 & 1 & 1 & 1 & 4 & 5 & 80 \\
$\mathrm{BRH}$ & 1 & 0 & 1 & 0 & 2 & 7 & 11 & 78 \\
$\mathrm{ISH}$ & 0 & 17 & 2 & 2 & 9 & 13 & 7 & 50 \\
\hline
\end{tabular}


iron ores depends on the type of iron ore. The $\mathrm{Hg}$ species that evolved during the heating treatment consisted of both $\mathrm{Hg}^{0}$ and $\mathrm{Hg}^{2+}$.

When the physical mixture of $\mathrm{HgCl}$ or $\mathrm{HgCl}_{2}$ and $\mathrm{Fe}_{2} \mathrm{O}_{3}$ was heated, the evolution profile showed that in addition to the evolution peak when the pure mercury chloride species was solely THTP, owing to a secondary reaction, a new evolution peak emerged on the high-temperature side. In the case of the physical mixture of $\mathrm{HgO}$ or $\mathrm{HgSO}_{4}$ and $\mathrm{Fe}_{2} \mathrm{O}_{3}$, the $\mathrm{Hg}$ evolution peak observed in the pure compounds shifted to the lower temperature side. The curve-fitting of $\mathrm{Hg}$ evolution behavior for iron ore indicated that the $\mathrm{Hg}$ species that evolved below $600^{\circ} \mathrm{C}$ were chlorides, sulfide, sulfate, and oxide species. However, the $\mathrm{Hg}$ species that evolved at temperatures above $600^{\circ} \mathrm{C}$, which account for most of the desorbed $\mathrm{Hg}$ in several ores, were unknown.

\section{Supporting Information}

Figure S1 in Supporting Information is apparatus of Temperature-Programmed Heat Treatment.

This material is available on the Journal website at https:// doi.org/10.2355/isijinternational.ISIJINT-2021-295.

\section{Acknowledgments}

This study was supported in part by a Grant-in-Aid for Challenging Research (Exploratory) from the Ministry of Education, Culture, Sports, Science and Technology, Japan, by the Iron and Steel Institute of Japan (ISIJ), and by the Steel Foundation for Environmental Protection Technology (SEPT).

\section{REFERENCES}

1) P. Charvát, L. Klimeš, J. Pospíšil, J. J. Klemeš and P. S. Varbanov: J. Clean. Prod., 267 (2020), 122087. https://doi.org/10.1016/j. jclepro.2020.122087

2) L. B. Clarke and L. L. Sloss: Trace Elements - Emissions from Coal Combustion and Gasification, IEACR/49, IEA Coal Research, London, (1992), 15.

3) M. Takaoka, K. Shiota and T. Kusakabe: Report of the Steel Foundation for Environmental Protection Technology (SEPT), SEPT, Tokyo, (2006)

4) AMAP and UN Environment: Technical Background Report for the
Global Mercury Assessment 2018, Arctic Monitoring and Assessment Programme and UN Environment Programme, Chemicals and Health Branch, Tromsø and Geneva, (2019).

5) S. Guo, J. Yang and Z. Liu: Energy Fuels, 23 (2009), 4817. https:// doi.org/10.1021/ef9002395

6) S. Guo, J. Yang and Z. Liu: Energy Fuels, 26 (2012), 3388. https:// doi.org/10.1021/ef201598d

7) M. A. Lopez-Anton, Y. Yuan, R. Perry and M. M. Maroto-Valer: Fuel, 89 (2010), 629. https://doi.org/10.1016/j.fuel.2009.08.034

8) M. Rumayor, N. Fernandez-Miranda, M. A. Lopez-Anton, M. DiazSomoano and M. R. Martinez-Tarazona: Fuel Process. Technol., 132 (2015), 9. https://doi.org/10.1016/j.fuproc.2014.12.032

9) M. Rumayor, M. Diaz-Somoano, M. A. Lopez-Anton and M. R. Martinez-Tarazona: Chemosphere, 119 (2015), 459. https://doi.org/ 10.1016/j.chemosphere.2014.07.010

10) L. Gao, Y. Wang, Q. Huang and S. Guo: Fuel, 200 (2017), 22. https:// doi.org/10.1016/j.fuel.2017.03.045

11) P. Xu, B. Zhang, X. Zeng, Y. Xu, G. Luo and H. Yao: Int. J. Coal Geol., 170 (2017), 14. https://doi.org/10.1016/j.coal.2016.08.023

12) N. Tsubouchi, Y. Mochizuki, Y. Ono, K. Uebo, T. Takanohashi and N. Sakimoto: ISIJ Int., 54 (2014), 2439. https://doi.org/10.2355/ isijinternational.54.2439

13) X. Liu, S. Wang, L. Zhang, Y. Wu, L. Duan and J. Hao: Fuel, 111 (2013), 621. https://doi.org/10.1016/j.fuel.2013.03.052

14) S.-K. Back, D. Bhatta, S.-H. Kim, H.-N. Jang, J.-H. Kim, K.-H. Kim, Y.-R. Kim and Y.-C. Seo: J. Mater. Cycles Waste Manag., 20 (2018), 622. https://link.springer.com/article/10.1007/s10163-017-0630-4

15) T. Zhao, X. Wang, X. Yang, X. Yan, Z. Nie and Q. Huang: J. Mater. Cycles Waste Manag., 19 (2017), 712. https://link.springer.com/ article/10.1007/s10163-016-0468-1

16) S. A. Tariq and J. O. Hill: J. Therm. Anal., 21 (1981), 277. https:// link.springer.com/article/10.1007/BF01914211

17) W. W. Wendlandt: Thermochim. Acta, 10 (1974), 101

18) Z. Zhu, Y. Zhuo, Y. Fan and Z. Wang: J. Environ. Sci., 43 (2016), 169. https://doi.org/10.1016/j.jes.2015.09.011

19) M. Rumayor, M. Díaz-Somoano, M. A. López-Antón, R. OchoaGonzález and M. R. Martínez-Tarazona: Fuel, 148 (2015), 98. https:// doi.org/10.1016/j.fuel.2015.01.101

20) M. A. Lopez-Anton, R. Perry, P. Abad-Valle, M. Díaz-Somoano, M. S. Martínez-Tarazona and M. M. Maroto-Valer: Fuel Process. Technol., 92 (2011), 707. https://doi.org/10.1016/j.fuproc.2010.12.002

21) M. Pavlin, A. Popović, R. Jaćimović and M. Horvat: Open Chem., 16 (2018), 544. https://doi.org/10.1515/chem-2018-0046

22) M. Rumayor, M. Diaz-Somoano, M. A. Lopez-Anton and M. R. Martinez-Tarazona: Talanta, 114 (2013), 318. https://doi.org/ 10.1016/j.talanta.2013.05.059

23 D. Saniewska and M. Bełdowska: Talanta, 168 (2017), 152. https:// doi.org/10.1016/j.talanta.2017.03.026

24) M. Sedlar, M. Pavlin, A. Popovič and M. Horvat: Open Chem., 13 (2015), 404. https://doi.org/10.1515/chem-2015-0051

25) S. Wu, M. A. Uddin, S. Nagano, M. Ozaki and E. Sasaoka: Energy Fuels, 25 (2011), 144. https://doi.org/10.1016/j.fuel.2013.07.021

26) T. Liu, L. Xue, X. Guo and C.-G. Zheng: Fuel, 115 (2014), 179.

27) B. V. L'vov: Thermochim. Acta, 333 (1999), 21. https://doi.org/ 10.1016/S0040-6031(99)00086-6 